\title{
A STUDY AMONG ENGLISH TEACHERS' PERCEPTIONS: INVESTIGATING THE ROLES OF ICT IN INDONESIAN EFL CLASSROOM
}

\author{
Khoirunnisa Isnani \\ Universitas Negeri Yogyakarta \\ khoirunnisaisnani.kn2@gmail.com
}

\begin{abstract}
The status of English as a foreign language in Indonesia makes the students use this language rarely. Whereas, English as international language and also a compulsory subject in secondary school to university level in Indonesia encourage students to master English. ICT comes with many advantages created innovation in teaching and learning English. Then, the teachers as the key role in the course should utilize it. However, the teachers should know the roles of ICT in teaching English. Therefore, this research aims to analyze English teachers' perceptions on the roles of ICT in EFL classroom. This descriptive qualitative research involved five English teachers from different schools in Yogyakarta, Indonesia. The research data were gathered using interview. The findings of the research showed that ICT plays role as a tool, a source, and an encouragement of students' English learning.
\end{abstract}

Keywords: ICT roles, English teaching, teachers' perception, EFL classroom

\section{A. INTRODUCTION}

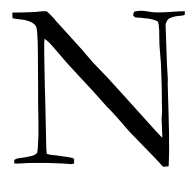

owadays, the English language teaching and learning is often associated with the use of Information and Communication Technology (ICT). ICT provide opportunities to English teachers and students to achieve learning goals effectively. It means that the English teachers as a key role in the success of English language teaching and learning process must be utilizing the technology advancement. Further, Indonesian Ministry of Education also encourage the teachers to implement ICT in their classrooms. It has been declared on the Ministry Decree Number 22 Year 2016 about Process Standard of Primary and Secondary Education in which one of the learning principles should be employing ICT to improve learning efficiency and effectiveness (Ministry of Education and Culture, 2016). Therefore, the involvement of ICT in English classroom is really recommended due to develop students' English performances.

On the other hand, English language as a foreign language in Indonesia makes rarely to be used by Indonesian students in their daily activities. Then, Indonesian English teachers need more effort in developing their students' English language skills. Afterward, some researchers identified several complex issues regarding English language teaching and learning in Indonesia context such as limited sources for teaching, teachers' lack of English proficiency and students' passive contribution in the classroom (Hidayati, 2016; Sulistiyo, 2016). Further, Hidayati (2016) 
adds that the common Indonesian ELT characteristic is a traditional teacher-centered style of teaching which makes students involved rarely in learning activities. Therefore, ICT comes as an innovation that offers to improve English language teaching and learning in Indonesian context.

However, before using ICT in English teaching, the teachers should know the role of ICT in their courses in order to be able to utilize it optimally. Hence, it is needed to know English teachers' perceptions on the role of ICT. This research comes to analyze their perception with a research question as follows: What are the teachers' perceptions on the role of ICT in Indonesian EFL classroom?

\section{B. REVIEW OF LITERATURE}

\section{ICT in EFL Classroom}

ICT stands for Information and Communication Technology. It is a kind of technology that help human in communicating includes information gathering. Blurton (1999, p. 1) defines ICT as "a various set of technological tools and resources used to communicate, and to create, disseminate, store, and manage information". In English language context, ICT has become a critical medium assisting English language teaching and learning. ICT provides rich sources to access authentic materials, such as video and podcasts that can be used to show the pronunciation of native speakers to the students (Cakici, 2016; Otero, 2016). Moreover, ICT can be employed to enhance students' language skills through various English teaching and learning activities (Kavitharaj, 2017; Kilickaya, 2018). For example, the students can check their writings through PowerPoint software in the computer which presents the correct form of erroneous words and structures of the text (Amirsheibani \& Iraji, 2014; Yunus et al., 2013). Moreover, ICT facilitates communication activities among teacher, students, and also native speakers, and the students are able to develop their communication skills by interacting with another students across the world (Dweikat, 2016). Therefore, it can be concluded that ICT has many advantages in assisting English language teaching and learning process.

\section{The Roles of ICT in English Teaching}

The technology development creates many changes in education time by time. It is in line with the statement of Parvin and Salam (2015) that ICT plays a role in the language classroom changing to be more innovative learning. Besides, ICT as a tool facilitates the students to learn English language and as a source provides access to authentic materials and the information that can supplement students' learning experiences (Ammanni \& Aparanjani, 2016; Fatimah \& Santiana, 2017; Haswani, 2014). Then, Ammanni and Aparanjani (2016) and Stockwell (2013) 
state that ICT is able to enhance students' motivation in learning English language. Further, internet allows students to learn English everywhere at any time, and the teachers also can use various ICT tools to teach language skills such as showing the pronunciation of native speakers through YouTube video and projector in the classroom (Ammanni \& Aparanjani, 2016). Rosdiana (2018) adds that the use of video is able to improve students' English listening comprehension ability. Another ICT tools that came in useful is audiobook in which can assist the students in reading independently and it will helpfully develop their reading and listening competences (Imawan \& Ashadi, 2019). Hence, it can be concluded that ICT plays important roles in English language teaching and learning.

\section{METHOD}

The researcher applied descriptive qualitative as the research design of this paper. According to Creswell (2008), qualitative research is a research that aims to investigate social issues and presented in the form of words with detailed description. Thus, this design is appropriate to the focus of this research which analyzed English teachers' perception on ICT role in Indonesian EFL classroom. Furthermore, the subjects of this research were five teachers from different school in Yogyakarta, Indonesia. Then, to gather the research data, the researcher employed interview as the research instrument. Interview is used to sample participants' perceptions on social situated of research data (Cohen, Manion, \& Morrison, 2011). Before collecting the data, the researcher designed an interview guidelines to make sure the researcher ask the same questions in research context to all participants. Likewise, the researchers made an appointment to match the participants' schedules in doing the interview. Moreover, the researcher analyzed the data using three flows including data reduction, data display, and drawing conclusion/verification (Miles \& Huberman, 1994). The purpose of this data analysis is to describe Indonesian English teachers' perceptions on the role of ICT in their classrooms.

\section{FINDINGS AND DISCUSSION}

In this section, the findings and discussion of the research are presented. The findings cover the analysis result from interview data on English teachers' perceptions on the role of ICT in Indonesian EFL classroom.

\section{The English teachers' perceptions on the roles of ICT in Indonesian EFL classroom.}

The analysis of interview data revealed that based on the teachers' perceptions, ICT plays role as a tool, a source, and an encouragement of students' English learning. 
Isnani, A Study among English Teachers'...

a. ICT as a tool

The interview data administered as follows:

"TCT helps the students to be more comprehended the lesson. Sometimes, the students need more clarification if they get an explanation from the teacher only. Thus, if the teacher use ICT, the media make the explanation more effective, and the students are able to understand the lesson easier."

Another data of interview presented as follows:

"In my opinion, ICT becomes a tool and a medium in teaching, so, there is something lose when teaching without ICT now."

Another data of interview presented as follows:

"TCT supports English teaching process as media that makes the teaching situation more interesting."

From the data above, it is shows that ICT plays a role as a medium tool to help the teachers in delivering the English materials. It goes in line with Ammanni and Aparanjani, (2016) that ICT becomes essential tools for assisting English teaching and learning process. Besides, Haswani (2014) also said that ICT serves as medium for local and global communication in which the teachers are able to collaborate with another teachers, and the students are able to develop their communication skill across the world.

b. ICT as a source

The next analysis, the researcher found another role of ICT as a source from the interview data below:

"... if teaching sources come from YouTube video for example, or usually the materials are accessed from English websites."

This statement showed that ICT can be used as a resource provided several English materials. It is in line with the statement of Haswani (2014) that ICT provides accesses to authentic materials. For example, the English teachers are able to deliver authentic materials such as videos and podcast from internet and then the students can assess their language skills by listening and observing body languages of native speakers (Cakici, 2016; Otero, 2016). Hence, ICT plays a role as a source that provides various language teaching materials.

c. ICT as an encouragement of students' English learning

The researcher found in the final analysis from the interview data was ICT plays a role as an encouragement of students' learning. The interview data presented as follows:

"... the teaching and learning process becomes more interesting."

The other interview data administered below:

"TCT makes the teaching process not boring, and it offers many interesting activities that enhance the students' attention and interest in learning English language." 
Another data of interview presented as follows:

"The students enjoy in doing learning activities through game, they look competitively in answering questions in the game."

It can be concluded that ICT plays a role as a motivating students' English learning in which they feel enjoy enhance their motivation in learning English. It is supported by the argument of Ammanni and Aparanjani (2016) that technology has become a source for motivating the students in English learning. Furthermore, Stockwell (2013) adds that integrating ICT in learning environments has the potential to encourage students' learning motivation. Thus, the students will be more active joining learning activities in the classroom, and the teacher-centered environment in the classroom will change into student-centered in which the students have many opportunities in developing their language abilities.

\section{E. CONCLUSION}

In this digital era, the advancement of technology brings many changes in every aspect including education. Then, English as a foreign language in Indonesia encourage teachers to be harder in helping the students mastering English language. English teacher as a key role in English classroom should create an innovative and interesting English course by utilizing various ICT tools. However, before using ICT in teaching, the teachers should know and understand what the roles of ICT in Indonesian EFL classroom are in order make the teachers are able to employ it optimally. Likewise, the researcher concluded three roles of ICT in English teaching as Indonesian teachers' perceptions. The findings showed that ICT plays a role as a tool, a source, and a motivating students' English learning.

\section{REFERENCES}

Amirsheibani, M., \& Iraji, M. (2014). CALL and teaching writing: Language teachers' attitude, An Iranian survey. International Conference on Current Trends in ELT. 98, pp. 258-266. Najafabad: Elsevier Ltd. doi:10.1016/j.sbspro.2014.03.415

Ammanni, S., \& Aparanjani, U. (2016). The role of ICT in English language teaching and learning. International Journal of Scientific \& Engineering Research, 7(7), 1-7.

Blurton, C. (1999). New Directions of ICT-Use in Education. New York: Learning Without Frontiers, UNESCO (LWF). 
Isnani, A Study among English Teachers'...

Cakici, D. (2016). The use of ICT in teaching English as a foreign language. Participatory Educational Research (PER), 4, 73-77.

Cohen, L., Manion, L., \& Morrison, K. (2011). Research methods in education (7th ed.). London: Routledge.

Creswell, J. W. (2008). Educational research: Plnning, Conducting, and Evaluating Quantitative and Qualitative Research (4th ed.). Boston: Pearson.

Dweikat, K. (2016). Impact of using Facebook on improving English communication skills: The case of implementing the English language course as a model at Al-Quds Open University. An - Najah Univ. J. Res. (Humanities), 30(11), 2287-2318.

Fatimah, A. S., \& Santiana. (2017). Teaching in 21st century: Students-teachers' perceptions of technology use in the classroom. Script Journal: Journal of Linguistic and English Teaching, 2(2), 125-135. doi:10.24903/sj.v2i2.132

Haswani, F. (2014). The role of technology in EFL classroom. International Journal of English and Education, 1(2), 107-118.

Hidayati, T. (2016). Integrating ICT in English language teaching and learning in Indonesia. Journal of English Education and Linguistics Studies (JEELS), 3(1), 38-62.

Imawan, M. R., \& Ashadi. (2019). Audiobooks for assisting EFL students in reading independently. JELTL (Journal of English Language Teaching and Linguistics), 4(1), 77-86.

Kavitharaj, K. (2017). ICT to enhance speaking skills. International Journal of English Language, Literature in Humanities (IJELLH), 5(9), 843-847.

Kilickaya, F. (2018). Information and communications technology (ICT) in listening instruction. The TESOL Encyclopedia of English Language Teaching, 1-7. doi:10.1002/9781118784235.eelt0601

Miles, M. B., \& Huberman, A. M. (1994). Qualitative data analysis: An expanded sourcebook (6th ed.). London: Sage Publications.

Otero, R. G. (2016). Innovative resources based on ICTs and authentic materials to improve EFL students' communicative needs. In A. Pareja-Lora, C. Calle-Martinez, \& P. 
Volume 5, Number 2, December 2019

Rodriguez-Arancon, New perspectives on teaching and working with languages in the digital era (pp. 83-93). Dublin: Research-publishing.net. doi:10.14705/rpnet.2016.tislid2014.424

Parvin, R. H., \& Salam, S. F. (2015). The effectiveness of using technology in English language classrooms in government primary schools in Bangladesh. Forum for International Research in Education, 2(1), 47-59.

Rosdiana. (2018). The use of audio visual as media in enhancing students' listening skill. Getsempena English Education Journal (GEEJ), 5(1), 146-149.

Stockwell, G. (2013). Technology and motivation in English-language teaching and learning. In E. Ushioda, International perspectives on motivation: Language learning and professional challenges (pp. 156-175). London: Palgrave Macmillan.

Sulistiyo, U. (2016). English language teaching and EFL teacher competence in Indonesia. Proceedings of the Fourth International Seminar on English Language and Teaching (ISELT-4) (pp. 396-406). Jambi: Igniting a Brighter Future of EFL Teaching and Learning in Multilingual Societies.

Yunus, M. M., Nordin, N., Salehi, H., Sun, C. H., \& Embi, M. A. (2013). Pros and cons of using ICT in teaching ESL reading and writing. International Education Studies, 6(7), 119-130. 